\title{
COMPARISON OF SEX STEROID CONCENTRATION IN BLOOD PLASMA AND OVARIAN FOLLICLES OF WHITE LEGHORN AND GREENLEG PARTRIDGE LAYING HENS*
}

\author{
Andrzej Sechman, Mirosława Staruszczak, Janusz Rząsa
}

\author{
Department of Animal Physiology and Endocrinology, University of Agriculture in Krakow, \\ Al. Mickiewicza 24/28, 30-059 Kraków, Poland \\ Corresponding author: rzsechma@cyf-kr.edu.pl
}

\begin{abstract}
The study was performed to compare plasma and ovarian levels of progesterone ( $(\mathrm{P} 4)$ and estradiol (E2) with laying rate in two different breeds of egg-type chickens, i.e. White Leghorn (WL) and Greenleg Partridge (GP). Thirty-five-week-old WL (line H22; $n=8$ ) and GP (line Z11; $n=8$ ) hens were used in the experiment. Blood samples were collected from hens at the time of $\mathrm{C}_{1}$ oviposition (i.e. $0.5 \mathrm{~h}$ before $\mathrm{C}_{2}$ ovulation), then at $20,16,12,8,4,2 \mathrm{~h}$ before $\mathrm{C}_{3}$ ovulation, and at the time of predicted $\mathrm{C}_{3}$ ovulation (i.e. just after $\mathrm{C}_{2}$ oviposition). On the following day, six birds of each breed were decapitated $2 \mathrm{~h}$ before ovulation on the next day after the last blood collection. A stroma, small (SWF; 1-4 mm), medium (MWF; 4-6 mm) and large (LWF; 6-8 mm) white prehierarchical follicles, and yellow hierarchical (F6-F1; 8-36 mm) ovarian follicles were isolated. P4 and E2 levels in blood plasma and ovarian follicles were determined radioimmunologically. The average rate of lay in WL hens was significantly higher than in GP hens $(P<0.05)$. The highest concentrations of $P 4$ and E2 were found $4 \mathrm{~h}$ before ovulation in both WL and GP hens. In WL hens the levels of P4 at the time of oviposition and at 4 and $2 \mathrm{~h}$ before ovulation were significantly higher in comparison with GP hens $(\mathrm{P}<\mathbf{0 . 0 5})$. On the other hand, higher $\mathrm{E} 2$ concentrations were found in GP hens at the time of oviposition and 12,8 and $4 \mathrm{~h}$ before ovulation $(P<0.05)$. In $L W F$ and hierarchical follicles of WL hens the level of $P 4$ was significantly lower than in GP hens $(P<0.05)$. With respect to E2, a reverse relationship was observed in LWF and F6-F4 follicles. In conclusion, the results obtained indicate that in egg-type layers the profiles of plasma and ovarian sex steroids depend on their genotype. The significant differences in sex steroid levels in blood and ovarian follicles of the WL and GP breeds may contribute to explain the endocrinological factors that determined their laying performance and productivity.
\end{abstract}

Key words: sex hormones, blood, ovulatory cycle, ovarian follicles, White Leghorn, Greenleg Partridge, hen

\footnotetext{
* This work was supported by DS-3243/KFiEZ.
} 
In the domestic hen, egg laying rate as well as the reproductive and breeding effects depend mainly on the number of developed oocytes in the ovary. Their growth and maturation in ovarian follicles are closely connected with endocrine changes, primarily with variations in circulating levels of gonadotropins and sex steroids (Johnson, 2000; Johnson and Woods, 2009). It is well accepted that ovulation in the laying hen is induced by a single preovulatory surge of luteinizing hormone (LH) which occurs approximately 6-4 h before ovulation (Wilson and Sharp, 1974; Johnson, 2000). It is induced by progesterone (P4), the plasma concentration of which coincides with the preovulatory LH peak (Shodono et al., 1975; Etches and Cunningham, 1976; Johnson and van Tienhoven, 1980). The second main steroid, which is involved in regulation of LH release from the pituitary gland, is estradiol (E2). The changes in the plasma concentrations of E2 during the ovulatory cycle are similar to those of $\mathrm{P} 4$. However, the highest concentration of this hormone in blood circulation appears 1-2 $\mathrm{h}$ before the increase in plasma P4 (Wilson and Sharp, 1976; Etches and Cheng, 1981; Johnson, 2000).

The main sources of sex steroids in blood circulation of the laying hen are granulosa and theca layers of ovarian follicles. The granulosa layer of the white non-hierarchical follicles is steroidogenically incompetent while the theca layer of these follicles produces mainly E2 (Nitta et al., 1991; Tilly et al., 1991; Lee et al., 1998; Johnson and Wood, 2009). During follicular growth and transition to the preovulatory hierarchy, the cells of the granulosa layer, stimulated mainly by follicle stimulating hormone (FSH), gradually increase synthesis and secretion of P4 (Bahr et al., 1983; Nitta et al., 1991; Kato et al., 1995; Woods and Johnson, 2005). Afterwards, the yellow hierarchical follicles, stimulated by LH, gradually potentiate P4 production by the granulosa cells so that the preovulatory follicle (F1) becomes the major source of this hormone in the circulation (Bahr et al., 1983; Nitta et al., 1991; Proszkowiec-Węglarz et al., 2005; Sechman et al., 2009).

The majority of studies concerning sex steroid concentrations in blood and ovarian follicles were carried out on egg-type chickens of the White Leghorn (WL) breed (Shodono et al., 1975; Bahr et al., 1983; Lebedev et al., 2006; Lebedeva et al., 2010). The present study has been conducted to characterize the ovulatory plasma pattern of sex steroids and their changes in ovarian follicles of Greenleg Partridge (GP) chickens which are a native breed of Polish layers kept in a closed population over 50 generations. These chickens demonstrate high resistance to low temperatures and diseases and an ability to lay eggs under a variety of environmental conditions. However, in comparison to WL breed, GP hens exhibit lower laying performance (Cywa-Benko, 2000). To our knowledge this is the first report comparing plasma and ovarian patterns of sex steroids in WL and GP laying hens.

\section{Material and methods}

\section{Animals}

The experiment was carried out on WL (line H22) and GP (line Z11) laying hens (35 weeks old) weighing an average of $1.94 \pm 0.063$ and $1.73 \pm 0.059 \mathrm{~kg}$, 
respectively. Hens were purchased from the Experimental Station of the National Research Institute of Animal Production in Chorzelów, Poland. Birds were housed in individual cages at neutral temperature $\left(18-20^{\circ} \mathrm{C}\right)$ under $14 \mathrm{~L}: 10 \mathrm{D}$ lighting schedule. They were provided with water and commercial feed ad libitum. Three weeks before the onset of the experiment oviposition time had been checked at 15-min intervals between $0700 \mathrm{~h}$ and $1600 \mathrm{~h}$. On the basis of recording of egg-laying, cloacal palpation and autopsy it was found that ovulation occurred within $30 \mathrm{~min}$ after oviposition of the previous egg in the series which took place between $0700 \mathrm{~h}$ and $1000 \mathrm{~h}$. Eight hens of each breed characterized by regular clutches of at least 8 eggs were selected for the experiment. The egg laying rate of WL and GP hens was recorded 10 days before and during the experiment.

\section{Blood sampling and tissue collection}

Blood samples were taken from the wing vein of each bird at the time of $\mathrm{C}_{1}$ oviposition (i.e. $0.5 \mathrm{~h}$ before $\mathrm{C}_{2}$ ovulation), at $20,16,12,8,4,2 \mathrm{~h}$ before $\mathrm{C}_{3}$ ovulation, and then at the time of predicted $\mathrm{C}_{3}$ ovulation (i.e. just after $\mathrm{C}_{2}$ oviposition). Ovulation was confirmed by the presence of an egg in the oviduct following the last blood sampling. On the third day of the experiment, six hens of each breed with hard egg in the shell gland were decapitated $2 \mathrm{~h}$ before $\mathrm{C}_{3}$ ovulation. The ovary was removed, weighed and placed in ice-cold sterile $0.9 \% \mathrm{NaCl}$ solution. Subsequently, stroma with cortical follicles $<1 \mathrm{~mm}$ in diameter, small white follicles $(>1-4$ $\mathrm{mm}$; SWF), medium white follicles ( $>4-6 \mathrm{~mm}$; MWF), large white (or yellowish) follicles $(>6-8 \mathrm{~mm}$; LWF) and 6 yellow hierarchical follicles $(>8-32 \mathrm{~mm}$; F6-F1, $\mathrm{F} 6<\mathrm{F} 5<\mathrm{F} 4<\mathrm{F} 3<\mathrm{F} 2<\mathrm{F} 1)$ were isolated from the ovary. The weight of ovarian stroma as well as the number and weight of all follicles in the given population and classes were recorded. Subsequently, the white and yellow follicles isolated from the ovaries of WL and GP hens were cleaned of yolk, and the follicular walls were weighed and kept at $-20^{\circ} \mathrm{C}$ until measurement of ovarian steroids.

\section{Sex hormone determination}

The concentration of steroids in collected ovarian tissues was determined according to a procedure described previously (Sechman et al., 2006; Hrabia et al., 2011). Briefly, the tissues were homogenized in liquid nitrogen and just before analysis dissolved in $0.1 \mathrm{M}$ phosphate buffer $(\mathrm{pH}=7.4)$. Concentrations of $\mathrm{P} 4$ and $\mathrm{E} 2$ in full homogenates of ovarian follicles and plasma samples were measured radioimmunologically using DSL kits (Diagnostic Systems Laboratories, Inc., USA), supplied by Nobipharm (Warsaw, Poland). They included standards, ${ }^{125}$ I-labelled hormone and test tubes coated with an appropriate antibody. The lowest limits of P4 and E2 assay sensitivity were $120 \mathrm{pg} / \mathrm{ml}$ and $11 \mathrm{pg} / \mathrm{ml}$, and mean recoveries 97.3 and $94.2 \%$, respectively. The intra- and interassay coefficients of variation were $6.5 \%$ and $11.7 \%$ for P4 and 3.4\% and 7.3\% for E2. The cross-reactions of P4 antibodies with pregnenolone, testosterone, and cortisol were undetectable. In the case of E2 antibodies, they exhibited $3.4 \%$ cross-reactivity with estrone and $0.75 \%$ with estriol but they did not exert cross-reactivity with testosterone or DHEA. The recoveries of exogenous P4 and E2 added to tissue homogenates were 92\% and 95\%, respectively. Steroid 
concentration was calculated per $\mathrm{ml}$ of blood plasma or per $\mathrm{mg}$ of gonadal tissue. The concentration of steroid hormones in ovarian follicles was expressed per $g$ of tissue.

\section{Statistical analyses}

Data on the progesterone and estradiol concentrations in blood plasma during the ovulatory cycle and in ovarian follicles were evaluated statistically by two-way ANOVA for repeated measurements followed by Duncan's multiple range test. Body weight and ovarian morphology parameters were analysed by Student's $t$-test while egg laying rate data by $\mathrm{z}$ test. Prior to the statistical analysis, normality of distribution was assessed using Shapiro-Wilk's test. Values were considered to be significant at $\mathrm{P}<0.05$ and highly significant at $\mathrm{P}<0.01$. The data are presented as means $\pm \mathrm{SEM}$. Statistical analyses were performed with SigmaStat 2.03 (SPSS Science Software, USA) while figures with Grapher 8.0 (Golden Software Inc., USA).

\section{Results}

\section{Egg laying rate}

The total egg production of WL and GP hens, recorded 10 days before and during the blood sampling, was $7.67 \pm 0.14$ and $6.92 \pm 0.19$ eggs/day, respectively (Figure 1b; $\mathrm{P}<0.05$ ). In comparison with $\mathrm{WL}$ hens, the rates of lay (number of eggs laid per day by a given group of hens) in GP hens between 9 and 6 days and on day 4 before blood sampling were lower (Figure 1a).

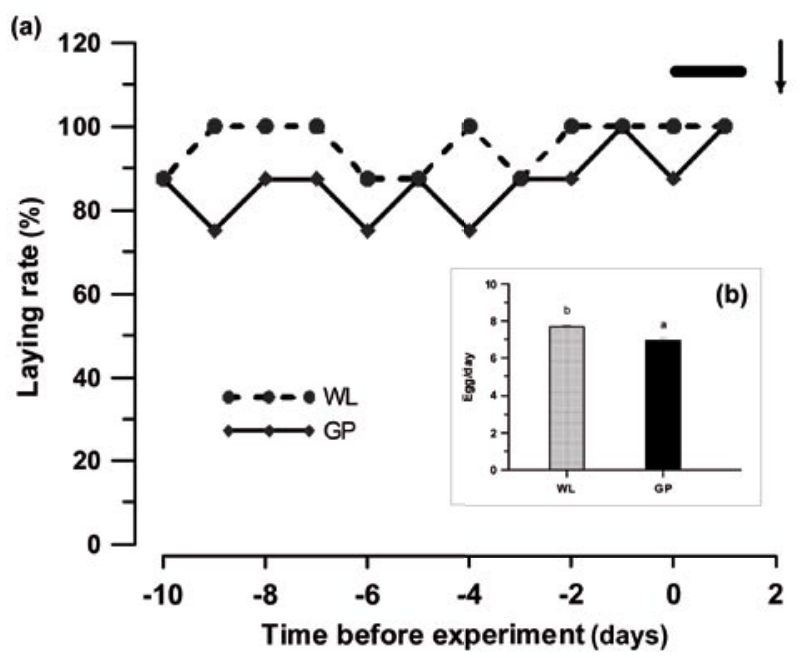

Figure 1. Changes in egg laying rate (a) and average laying rate (b) of White Leghorn (WL) and Greenleg Partridge (GP) hens. Each point represents the value from 8 hens. The horizontal bar represents time of blood sampling and the arrow indicates the time of bird decapitation. Values marked with different letters differ significantly $(\mathrm{P}<0.05)$ 


\section{Ovarian morphology}

Table 1 summarizes the recorded parameters of ovarian morphology of WL and GP laying hens. Results presented herein indicate that ovary weight of WL hens was approximately $11 \%$ greater than that of GP hens $(\mathrm{P}<0.05)$. However, relative to body weight the difference was not statistically significant. Ovaries of WL hens contained more SWF and LWF follicles in comparison with GP hens $(\mathrm{P}<0.05)$, but total weights of these follicles were not statistically significant. No significant differences in number and total weight of MWF as well as in total weight of yellow hierarchical follicles and ovarian stroma were observed between WL and GP laying hens (Table 1).

Table 1. Body weight and ovarian morphology parameters in White Leghorn (WL) and Greenleg Partridge (GP) laying hens

\begin{tabular}{lcc}
\hline \multicolumn{1}{c|}{ Characteristic } & WL & GP \\
\hline Body weight $(\mathrm{g})$ & $1939.2 \pm 63.2 \mathrm{a}$ & $1730.6 \pm 59.6 \mathrm{~b}$ \\
Ovary weight (g) & $57.23 \pm 3.53 \mathrm{a}$ & $51.55 \pm 1.45 \mathrm{~b}$ \\
Ovary weight (\% of body weight) & $2.95 \pm 0.10$ & $2.99 \pm 0.14$ \\
Number of SWF & $40.17 \pm 3.34 \mathrm{a}$ & $31.6 \pm 2.16 \mathrm{~b}$ \\
Total weight of SWF (g) & $0.76 \pm 0.08$ & $0.61 \pm 0.11$ \\
Number of MWF & $9.00 \pm 1.59$ & $7.01 \pm 0.71$ \\
Total weight of MWF (g) & $0.65 \pm 0.13$ & $0.63 \pm 0.14$ \\
Number of LWF & $6.17 \pm 0.57 \mathrm{a}$ & $4.80 \pm 0.33 \mathrm{~b}$ \\
Total weight of LWF (g) & $1.12 \pm 0.19$ & $0.83 \pm 0.16$ \\
Total weight of yellow hierarchical follicles F6-F1 (g) & $46.36 \pm 3.64$ & $44.03 \pm 1.13$ \\
Stroma weight (g) \# & $4.65 \pm 0.22$ & $4.21 \pm 0.30$ \\
\hline
\end{tabular}

Values are expressed as means $\pm \mathrm{SE}(\mathrm{n}=6)$. Means within a row with different letter differ significantly $(\mathrm{P}<0.05)$. SWF - small white follicles $(1-4 \mathrm{~mm})$; MWF - medium white follicles $(4-6 \mathrm{~mm})$; LWF - large white follicles $(6-8 \mathrm{~mm})$.

\# The stroma weight was comprised of the ovarian tissue remaining after white prehierarchical, yellow hierarchical and postovulatory (not shown in the Table) follicles were removed.

\section{Sex hormone levels in blood plasma}

The plasma patterns of P4 and E2 in blood plasma of WL and GP chickens are presented in Figures $2 \mathrm{a}$ and $2 \mathrm{~b}$, respectively. The concentration of $\mathrm{P} 4$ in WL birds $0.5 \mathrm{~h}$ before $\mathrm{C}_{2}$ ovulation was $1.48 \pm 0.13 \mathrm{ng} / \mathrm{ml}$; it was $31 \%$ lower in comparison with GP hens $(\mathrm{P}<0.05$; Figure $2 \mathrm{a})$. The $\mathrm{P} 4$ concentration in plasma of WL chickens significantly decreased to $0.60 \pm 0.05 \mathrm{ng} / \mathrm{ml}$ at $20 \mathrm{~h}$ of the ovulatory cycle $(\mathrm{P}<0.05)$, and subsequently gradually increased to $1.24 \pm 0.31 \mathrm{ng} / \mathrm{ml}$ at $12 \mathrm{~h}$ of the ovulatory cycle $(\mathrm{P}<0.05)$. There were no significant differences in plasma $\mathrm{P} 4$ concentration among WL and GP hens between 20 and $8 \mathrm{~h}$ before $\mathrm{C}_{3}$ ovulation. A sharp increase in $\mathrm{P} 4$ concentration in WL hens to the maximal level of $3.40 \pm 0.31 \mathrm{ng} / \mathrm{ml}$ at $4 \mathrm{~h}$ before $\mathrm{C}_{3}$ ovulation was observed $(\mathrm{P}<0.01)$. In comparison with WL birds, the plasma level of $\mathrm{P} 4$ in GP hens at 4 and $2 \mathrm{~h}$ before $\mathrm{C}_{3}$ ovulation was 26 and $21 \%$ lower, respectively 
$(\mathrm{P}<0.05)$. At the time of $\mathrm{C}_{3}$ ovulation the concentration of $\mathrm{P} 4$ in plasma of WL and GP hens returned to the basal level (Figure 2a).

(a)
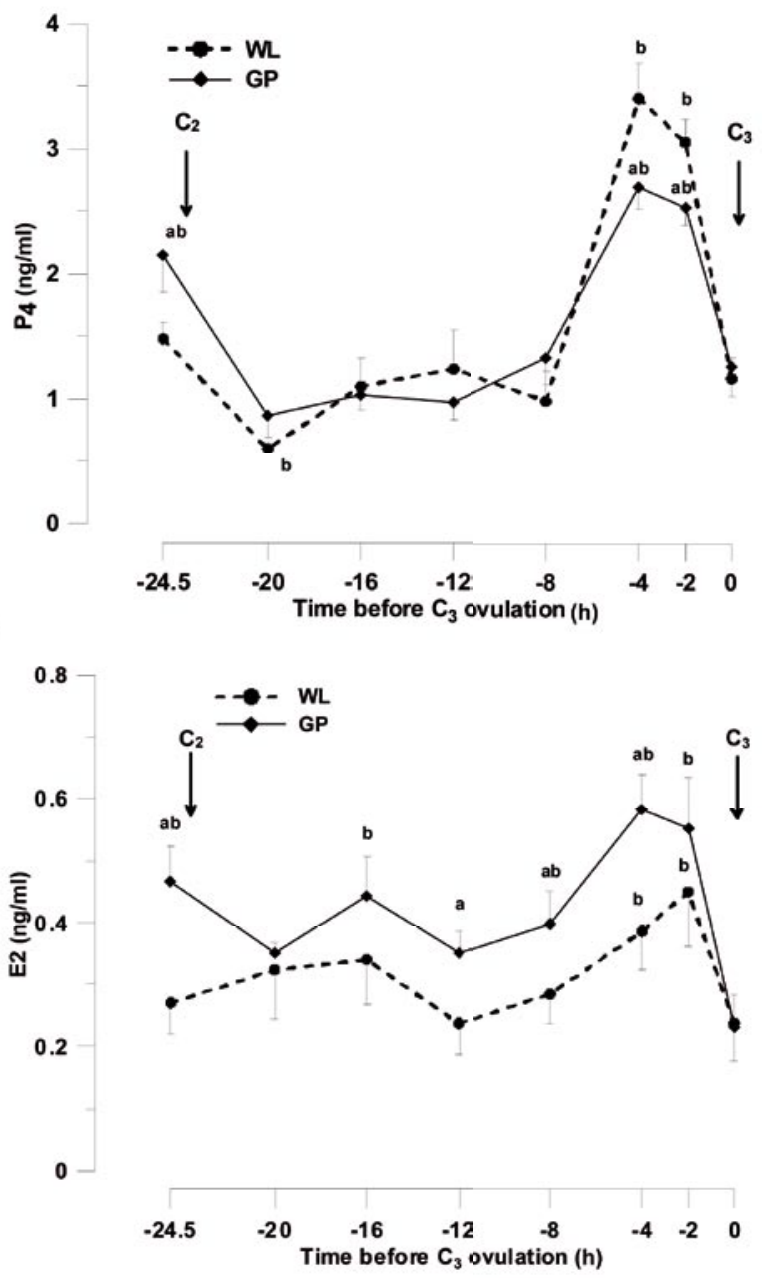

Figure 2. Patterns of plasma concentration of progesterone (P4) (a) and estradiol (E2) (b) during ovulatory cycle of White Leghorn (WL) and Greenleg Partridge (GP) hens. Each point represents the mean \pm SEM from 8 birds. $\mathrm{C}_{2}$ and $\mathrm{C}_{3}$ - indicate time of the second and third ovulation in the clutch; $\mathrm{a}-$ statistically significant in comparison with the corresponding value of WL hens $(\mathrm{P}<0.05) ; \mathrm{b}-$ statistically significant in comparison with the value obtained at the time of ovulation $(\mathrm{t}=$ " 0 "; $\mathrm{P}<0.05)$

In WL hens, E2 concentration in blood plasma $0.5 \mathrm{~h}$ before $\mathrm{C}_{2}$ ovulation was $0.27 \pm 0.05 \mathrm{ng} / \mathrm{ml}$, and did not change significantly until $8 \mathrm{~h}$ of the ovulatory cycle (Figure $2 \mathrm{~b}$ ). However, from the 12 th hour before $\mathrm{C}_{3}$ ovulation a gradual elevation of E2 concentrations in blood plasma of WL hens towards the maximal value of $0.45 \pm 0.08 \mathrm{ng} / \mathrm{ml}$ at $2 \mathrm{~h}$ before $\mathrm{C}_{3}$ ovulation was observed. At the time of the $\mathrm{C}_{3}$ ovulation, a sharp decrease in E2 level in plasma of WL hens to $0.24 \pm 0.06 \mathrm{ng} / \mathrm{ml}$ was 
found ( $\mathrm{P}<0.05$; Figure $2 \mathrm{~b}$ ). In comparison to WL chickens, the levels of $\mathrm{E} 2$ in blood plasma of GP hens were $73 \%$ higher $0.5 \mathrm{~h}$ before $\mathrm{C}_{2}$ ovulation and $52 \%, 42 \%$ and $51 \%$ higher at 12,8 and $4 \mathrm{~h}$ before $\mathrm{C}_{3}$ ovulation, respectively $(\mathrm{P}<0.05$; Figure $2 \mathrm{~b})$.

\section{Sex hormone levels in ovarian follicles}

The level of $\mathrm{P} 4$ in the white prehierarchical and yellow hierarchical ovarian follicles of WL and GP hens is shown in Figures 3a and 3b, respectively. In WL hens, the lowest P4 levels were found in the ovarian stroma $(0.79 \pm 0.11 \mathrm{ng} / \mathrm{g}$ tissue). In SWF follicles the level of $\mathrm{P} 4$ was $91 \%$ higher than that in the stroma $(\mathrm{P}<0.01$; Figure $3 \mathrm{a})$. The level of P4 in all classes of white follicles was comparable. There were no differences in P4 concentrations between WL and GP hens in the stroma, SWF and MWF follicles; however, in LWF follicles of GP hens it was greater by $124 \%(\mathrm{P}<0.01$; Figure 3a).

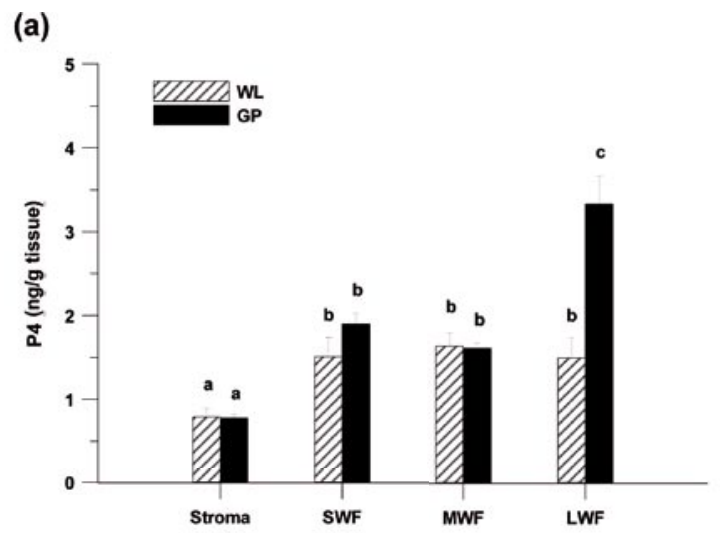

(b)

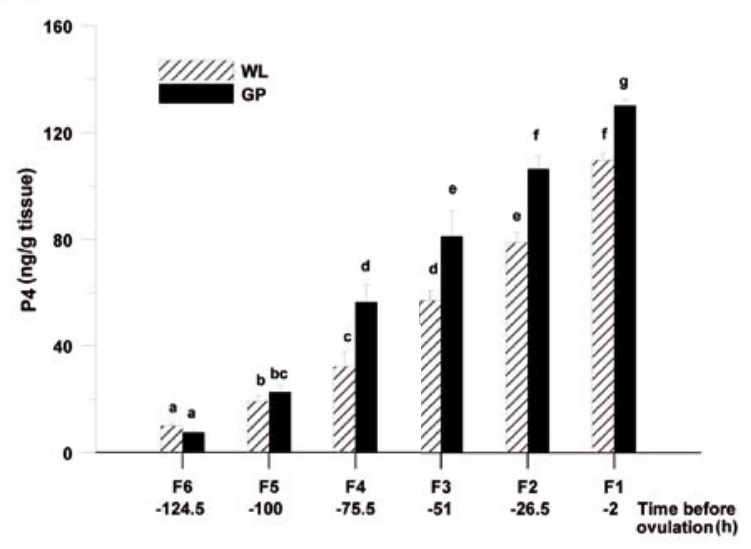

Figure 3. Progesterone (P4) levels in the stroma containing cortical follicles and the wall of small (SWF), medium (MWF) and large (LWF) white prehierarchical follicles (a) and yellow hierarchical (F6-F1; b) ovarian follicles of White Leghorn (WL) and Greenleg Partridge (GP) hens. Each value represents the mean \pm SEM from 6 birds. Values marked with different letters differ significantly 
In hierarchical follicles $(\mathrm{F} 6 \rightarrow \mathrm{F} 1)$ of $\mathrm{WL}$ and GP hens a gradual increase in P4 level from $10.01 \pm 0.92$ and $7.68 \pm 0.74 \mathrm{ng} / \mathrm{g}$ tissue in the $\mathrm{F} 6$ follicle to $109.5 \pm 2.84$ and $129.9 \pm 2.28 \mathrm{ng} / \mathrm{g}$ in the $\mathrm{F} 1$ follicle, respectively, was observed $(\mathrm{P}<0.01$; Figure $3 \mathrm{~b})$. In comparison to WL hens, the level of P4 in F4, F3, F2 and F1 follicles of GP chickens was higher by $76 \%, 42 \%, 34 \%$ and $18 \%$, respectively $(\mathrm{P}<0.05$; Figure $3 \mathrm{~b}$ ).

The highest E2 concentration (72.80 $\pm 8.4 \mathrm{ng} / \mathrm{g}$ tissue) was found in SWF follicles in the ovary of WL hens. It was 6.1-, 2.1- and 3.2-fold higher in comparison with the stroma and white MWF and LWF follicles, respectively $(\mathrm{P}<0.01$; Figure $4 \mathrm{a})$. There were no significant differences in E2 concentration in the stroma and white follicles between WL and GP chickens (Figure 4a).

(a)

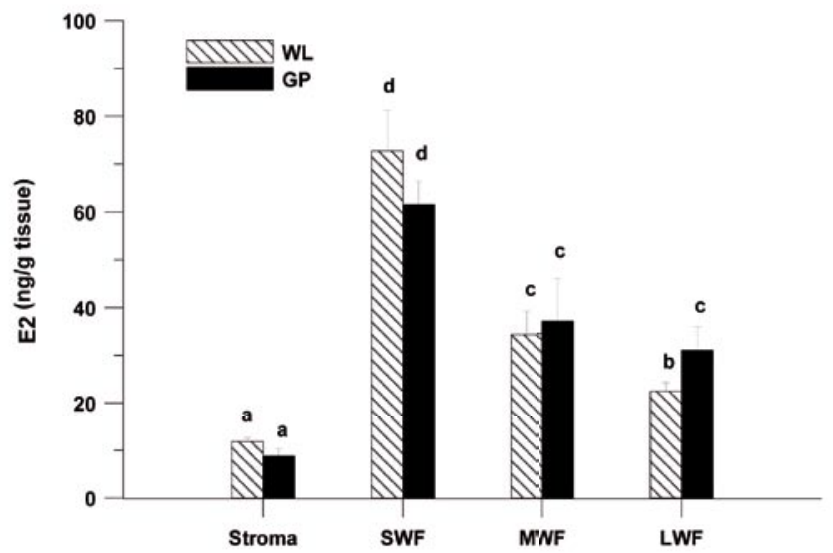

(b)

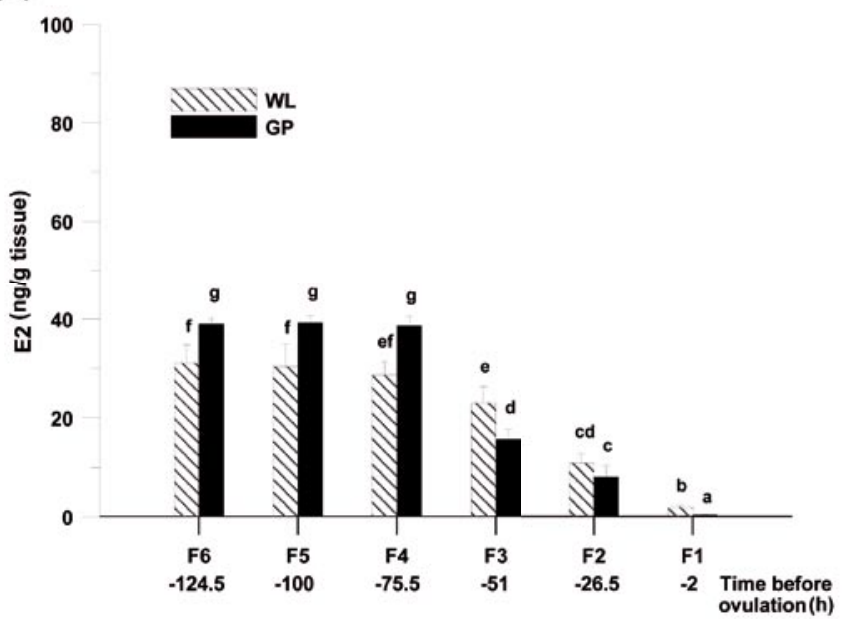

Figure 4. Estradiol (E2) levels in the stroma containing cortical follicles and the wall of small (SWF), medium (MWF) and large (LWF) white prehierarchical follicles (a) and yellow hierarchical (F6-F1; b) ovarian follicles of White Leghorn (WL) and Greenleg Partridge (GP) hens. For further explanations see Figure 3 
A gradual decrease in E2 concentration in the yellow hierarchical follicles during their growth and maturation was observed (Figure 4b). In WL hens the E2 level was $31.1 \pm 3.6 \mathrm{ng} / \mathrm{g}$ tissue in $\mathrm{F} 6$ follicle and $1.9 \pm 0.4 \mathrm{ng} / \mathrm{g}$ in $\mathrm{F} 1$ follicle $(\mathrm{P}<0.01$; Figure $4 \mathrm{~b})$. A similar pattern of E2 concentration in the yellow hierarchical follicles was noticed in GP hens; however, in comparison to WL chickens E2 concentration in the wall of F6, F5 and F4 follicles of GP hens was higher by $25 \%, 30 \%$, and $35 \%$, respectively $(\mathrm{P}<0.05)$. On the other hand, in F3 and F1 preovulatory follicles the level of E2 in GP hens was correspondingly lower by $32 \%$ and $81 \%(\mathrm{P}<0.05-0.01$; Figure $4 \mathrm{~b})$.

\section{Discussion}

The present study clearly demonstrates that there are only small differences in the ovarian morphology between WL and GP hens. Although the ovary of WL hens weighed more than the ovary of GP hens, there were no differences in their weight in relation to body mass. On the other hand, in the ovary of WL hens we found more SWF and LWF follicles which might potentially be selected into preovulatory hierarchy. This observation, at least partly, may explain the higher ovulatory potential of WL hens in comparison to GP hens.

In birds, egg production is controlled by the rate of growth and differentiation of ovarian follicles that are, in turn, under the control of reproductive hormones including gonadotropins, growth factors and sex steroids. The extent to which the levels of these hormones are linked with the laying rate of the hen is still not well established. Changes in sex steroid levels in blood plasma of WL laying chickens during the ovulatory cycle have been extensively studied in the past, but to our knowledge, this is the first report showing ovarian steroid profile in the ovulatory cycle of GP laying chickens. In the present study, both in WL and GP laying hens, a pronounced increase in plasma P4 and E2 concentrations was found between 4 and $2 \mathrm{~h}$ before ovulation. Moreover, in both breeds a significantly higher concentration of P4 was noticed at the time of oviposition (i.e. about $0.5 \mathrm{~h}$ before $\mathrm{C}_{2}$ ovulation). These results are consistent with previous investigations showing similar plasma profile of these hormones during the ovulatory cycle in WL hens (Shodono et al., 1975; Johnson and Van Tienhoven, 1980; Etches and Cheng, 1981; Lebedev et al., 2006; Sechman et al., 2006). The statistical analysis revealed that P4 concentration in GP hens at 4 and $2 \mathrm{~h}$ before ovulation was significantly lower in comparison to WL hens. Taking into consideration that the rise of $\mathrm{P} 4$ prior to ovulation is responsible for triggering the pre-ovulatory surge of LH (Etches and Cunningham, 1976, Wilson and Sharp, 1976) and injection of P4 can induce both preovulatory surge of LH and premature ovulation (Wilson and Sharp, 1975; Nakada et al., 1994), it cannot be excluded that the lower P4 concentration in blood circulation of GP laying hens found before ovulation is responsible for the lower rate of ovulation in this breed in comparison with WL hens. In this study, GP hens were characterized by a lower rate of egg laying in comparison with WL hens. Moreover, it has been previously reported that hens of the GP breed during the whole egg laying period exhibit lower egg laying rate than WL hens (Cywa-Benko, 2000). 
In WL chickens the level of E2 in blood plasma was relatively stable; however, between 12 and $2 \mathrm{~h}$ before $\mathrm{C}_{3}$ ovulation it gradually increased towards the maximal value at the second hour before ovulation. A similar elevation in E2 concentrations with the plasma peak few hours before ovulation was also reported in previous investigations (Shodono et al., 1975; Etches and Cheng 1981; Lebedev et al., 2006; Sechman et al., 2006). In GP hens the pattern of plasma E2 during the ovulatory cycle was parallel to that observed in WL hens, but contrary to $\mathrm{P} 4$ concentration, in GP hens $\mathrm{E} 2$ concentrations were significantly higher $0.5 \mathrm{~h}$ before $\mathrm{C}_{2}$ ovulation as well as between 12 and $4 \mathrm{~h}$ before $\mathrm{C}_{3}$ ovulation. It is well known that the elevation of $\mathrm{E} 2$ in blood plasma before ovulation is necessary to prime the hypothalamus and the pituitary in order to induce GnRH and LH release (Wilson and Sharp, 1976; Kawashima et al., 1992; Takahashi and Kawashima, 2009). Moreover, it has been shown that this steroid controls the ovarian functions by (a) direct influence on $\mathrm{P} 4$ production by granulosa cells of the hen ovarian follicles (Sasanami and Mori, 1999); (b) prevention of apoptosis and stimulation of proliferation (Monroe et al., 2002); (c) regulation of vitellogenesis process (Sakimura et al., 2001). Recently, Lebedeva et al. (2010) have demonstrated that in reproductive age hens of the WL breed a decline in the production of E2 in the middle of the ovulatory cycle may be one of the stimuli causing the follicular tissues to grow. However, this relationship was not associated with direct suppressive action of E2 on proliferation since this hormone raised the proliferative activity of granulosa cells and did not affect that of theca cells (Lebedeva et al., 2010). Therefore, it seems plausible that in the laying hen the appropriate P4 to E2 ratio in blood circulation, which occurs during the critical phase of the ovulatory cycle (i.e. from 4 to $2 \mathrm{~h}$ before ovulation), is responsible for the marked differences in reproductive performances. This assumption can be supported by the calculated $\mathrm{P} 4 / \mathrm{E} 2$ molar ratios which were greater by $83 \%$ and $54 \%$ at 4 and $2 \mathrm{~h}$ before $\mathrm{C}_{3}$ ovulation in WL hens in comparison with GP hens, respectively $(\mathrm{P}<0.01)$.

Since the main source of sex steroids in blood circulation is the ovary, in this experiment we measured P4 and E2 levels in the stroma and ovarian follicles $2 \mathrm{~h}$ before ovulation. Patterns of follicular P4 and E2 alterations in the stroma and ovarian follicles of WL and GP hens were similar to those described in earlier investigations (Bahr et al., 1983; Kato et al., 1995; Sechman et al., 2006; Rząsa et al., 2009). The lowest P4 levels were detected in the stroma while the highest in the F1 follicle. In the walls of preovulatory follicles $(\mathrm{F} 6 \rightarrow \mathrm{F} 1)$ a gradual increase in $\mathrm{P} 4$ concentration was observed. In respect of E2, the highest level of this steroid was noticed in SWF follicles. Both in white non-hierarchical and in yellow hierarchical follicles a steady decrease in E2 levels was found. The described changes of P4 and E2 levels in ovarian follicles of WL and GP hens can be explained by steroidogenic activity of the granulosa and theca layers of white and yellow follicles during their growth and maturation. The granulosa layer of white follicles $(<8 \mathrm{~mm})$ is steroidogenically inactive due to lack of cholesterol side-chain cleavage $\left(\mathrm{P}_{50} 0_{\mathrm{SCC}}\right)$ activity and in consequence incapability of P4 synthesis (Nitta et al., 1991; Tilly et al., 1991). However, the stroma and the theca layer of white follicles first produce P4 which is immediately converted to testosterone and then by aromatase P450 (P450arom) into E2 (Lee and Bahr, 1994; Lee et al., 1998). During the transition of the non-hierarchi- 
cal follicles to preovulatory hierarchy, the cells of the granulosa layer stimulated by LH express both $\mathrm{P}^{4} 50_{\mathrm{SCC}}$ and 3ß-hydroxysteroid dehydrogenase (3ß-HSD), and start to produce P4. The major site of P4 synthesis in the hen ovary is the granulosa layer of the largest yellow preovulatory follicles (Bahr et al., 1983; Nitta et al., 1991; Gomez et al., 1998; Proszkowiec-Węglarz et al., 2005; Sechman et al., 2009). A steady decrease in E2 concentration in yellow preovulatory follicles is associated with a gradual reduction of P450arom activity in the theca externa of these follicles (Bahr et al., 1983; Armstrong, 1984; Kato et al., 1995; Gomez et al., 1998).

The most outstanding findings of this study were discrepancies between ovarian and plasma levels of P4 in WL and GP hens. There were no marked differences in P4 levels between WL and GP hens in the ovarian stroma with cortical follicles, SWF and MWF follicles. However, in LWF and F4-F1 yellow preovulatory follicles the levels of P4 in WL hens were significantly lower. Unexpectedly, the level of P4 in these follicles did not resemble its concentration in blood plasma, because $2 \mathrm{~h}$ before ovulation plasma concentration of P4 in WL hens was significantly elevated in comparison with GP hens. The opposite relationship between follicular and plasma P4 levels was found in GP hens. To explain those results, we suggest that in good layers (i.e. WL hens) P4, synthesized mainly by the granulosa layer of preovulatory follicles (Bahr et al., 1983; Nitta et al., 1991), is not accumulated in the wall of these follicles but is immediately released into circulation increasing the concentration of this steroid in blood plasma. Moreover, it cannot be excluded that in WL hens higher amounts of $\mathrm{P} 4$ can be quickly transferred into theca layer since the higher concentrations of E2 were found in the wall of F3-F1 follicles of WL hens. In these follicles P4 might be quickly converted to androgens and estrogens in the cells of theca interna and externa, respectively (Nitta et al., 1991; Lee et al., 1998). The higher levels of P4 in preovulatory follicles of WL hens can be also connected with a lower level of E2 which was detected in the LWF follicles and yellow F6-F4 hierarchical follicles. Our previous study (Sechman et al., 2003) showed that administration of Fadrozole (a non-steroidal aromatase inhibitor) to laying hens for 6 succeeding days not only decreased E2 concentration in blood plasma and all classes of white follicles and F6-F4 yellow follicles but also significantly increased P4 synthesis by the two largest preovulatory follicles (F2 and F1). Therefore, it seems likely that lower E2 concentration is necessary to increase $\mathrm{P} 4$ secretion from preovulatory follicles. This assumption can be supported by earlier studies of Johnson et al. (1988) who reported that E2 suppressed LH-stimulated progesterone production from granulosa cells of preovulatory follicles. Subsequently, Lee and Bahr (1990) showed that estradiol acts as a competitive inhibitor of $3 \beta$-HSD which converts pregnenolone to progesterone.

In the present experiment the higher concentrations of E2 were found in SWF follicles; however, other classes of white non-hierarchical follicles as well as F6-F4 yellow hierarchical follicles were also characterized by relatively high E2 levels. These results are consistent with previous investigations which showed that in laying hens yellow hierarchical follicles are an equally important source of E2 as stroma and white non-hierarchical follicles (Armstrong, 1984; Proszkowiec-Węglarz et al., 2005). The levels of E2 in the stroma, SWF and MWF follicles were similar in WL and GP hens. However, significantly higher levels of this steroid were noticed in 
the wall of LWF and yellow F6-F4 follicles in GP hens than in WL hens. It seems likely that the higher plasma concentration of E2 in GP hens results from an elevated synthesis and secretion of this steroid by these follicles. It can be speculated that the observed alterations in E2 concentration between these two breeds of chickens result from marked differences in P450arom activity in the theca layer of LWF and F6-F4 follicles. Further molecular studies are necessary to clarify the nature of the differences between WL and GP laying hens in respect of ovarian steroidogenesis and its relationship with reproductive performances.

In conclusion, the results of the study showed that genotype of the egg-type layers affects plasma and ovarian sex steroids concentration that in turn may regulate reproductive parameters. The laying hens of the WL and GP breeds exhibited significant alterations in the pattern of plasma progesterone and estradiol during the ovulatory cycle as well as in their levels in ovarian follicles. Further investigations are needed to elucidate the nature of the observed steroid hormone relationship in blood circulation and the ovary of WL and GP hens, and their significance for chicken reproduction.

\section{References}

Armstrong D.G. (1984). Ovarian aromatase activity in the domestic fowl (Gallus domesticus). J. Endocrinol., 100: 81-86.

B ahr J.M., Wang S.-C., Huang M.Y., Calvo F.O. (1983). Steroid concentrations in isolated theca and granulosa layers of preovulatory follicles during the ovulatory cycle of the domestic hen. Biol. Reprod., 29: 326-334.

C yw a-B e n ko K. (2000). Native breeds of layers suitable for organic farming. World Poultry Sci. J., 16: 38-39.

Etches R.J., Cheng K.W. (1981). Changes in the plasma concentrations of luteinizing hormone, progesterone, oestradiol and testosterone and the binding of follicle-stimulating hormone to theca of follicles during the ovulation cycle of the hen (Gallus domesticus). J. Endocrinol., 91: 11-22.

Etches R.J., Cunning ham F.J. (1976). The interrelationship between progesterone and luteinizing hormone during the ovulatory cycle of the hen (Gallus domesticus). J. Endocrinol., 71: 51-58.

Gomez Y., Velazquez P.N., Juarez-Oropeza M.A., Pe dernera E. (1998). Steroid metabolism in granulosa and theca interna cells from preovulatory follicles of domestic hen (Gallus domesticus). Anim. Reprod. Sci., 52: 81-91.

Hrabia A., S e chman A., Gertler A., Rzą s J. (2011). Effect of growth hormone on steroid content, proliferation and apoptosis in the chicken ovary during sexual maturation. Cell Tissue Res., 345: 191-202.

J o h n s o n A.L. (2000). Reproduction in the female. In: G.C. Whittow (Editor), Sturkie's Avian Physiology, Academic Press, San Diego, London, Boston, New York, Sydney, Tokyo, Toronto, pp. 569-596.

Johns on A.L., van Ti e n hoven A. (1980). Plasma concentration of sex steroids and LH during the ovulatory cycle of hen (Gallus domesticus). Biol. Reprod., 32: 386-393.

Johnson A.L., Woods D.C. (2009). Dynamics of avian ovarian follicle development: cellular mechanisms of granulosa cell differentiation. Gen. Comp. Endocrinol., 163:12-17.

J o h n s o n A.L., G r e e n C., L e e H.T., B a hr J.M. (1988). Inhibition of progesterone secretion from granulosa cells by estradiol and androgens in the domestic hen. Endocrinology, 123: 473-477.

K a to M., S h i m a d a K., S a it o N., N o d a K., O h t a M. (1995). Expression of P450 178 -hydroxylase and $\mathrm{P} 450_{\text {aromatase }}$ genes in isolated granulosa, theca interna and externa layers of chicken ovarian follicles during follicular growth. Biol. Reprod., 52: 405-410. 
Kaw a sh im a M., Uk a i A., K a mi y o s h i M., T a n a k a K. (1992). Effect of progesterone in vitro on luteinizing hormone production in hen pituitary cells pretreated with estrogen. Poultry Sci., 71: $1215-1220$.

L e be d e v V.A., L e b e d e va I.Y., Gros s mann R., K u z min a T.I., P a rvi zi N. (2006). Ovulatory cycle-related alterations in the thecal growth and membrane protein content of thecal tissue of hen preovulatory follicles. Theriogenology, 66: 217-223.

L ebedeva I.Y., L e bedev V.A., Gross mann R., Parvizi N. (2010). Age-dependent role of steroids in the regulation of growth of the hen follicular wall. Reprod. Biol. Endocrinol., 8: 1-13.

L e e H.T., B a h r J.M. (1990). Inhibition of the activities of P450 cholesterol side-chain cleavage and 3ß-hydroxysteroid dehydrogenase and the amount of P450 cholesterol side-chain cleavage by testosterone and estradiol-17ß in hen granulosa cells. Endocrinology, 126: 779-786.

L e e K.A, B a h r J.M. (1994). Utilization of substrates for testosterone and estradiol-17ß production by small follicle of chicken ovary. Dom. Anim. Endocrinol., 11: 307-314.

L e e K.A., V o l e n t i n e K.K., B a h r J.M. (1998). Two steroidogenic pathways present in the chicken ovary: theca layer prefers $\Delta^{5}$ pathway and granulosa layer prefers $\Delta^{4}$ pathway. Dom. Anim. Endocrinol., 15: 1-8.

M o n ro e D.G., B e r g e r R.R., S a n d e r s M.M. (2002). Tissue protective effects of estrogen involve regulation of caspase gene expression. Mol. Endocrinol., 16: 1322-1331.

N a k a d a T., K o j a Z., T a n a k a K. (1994). Effect of progesterone on ovulation in the hypophysectomised hen. Brit. Poultry Sci., 35: 153-156.

Nitt a H., O s aw a Y., B ahr J.M. (1991). Immunolocalization of steroidogenic cells in small follicles of the chicken ovary: anatomical arrangement and location of steroidogenic cells change during follicular development. Dom. Anim. Endocrinol., 8: 587-594.

Pros zk ow i e c - W ęg l ar z M.,R z ą s a J.,S ł o m c z yń s k a M.,P a c z o s k a - E li a s i e wic z H. (2005). Steroidogenic activity of chicken ovary during pause in egg laying. Reprod. Biol., 5: $205-225$.

Rząs a J., S e chman A., Paczoska-Elias iew ic z H., Hrabia A. (2009). Effect of tamoxifen on sex steroid concentrations in chicken ovarian follicles. Acta Vet. Hung., 57: 85-97.

Sakimura M., Hanazawa S., Tsukada A., Yamamoto I., Saito N., Usami M., Ohnoy, Shimada K. (2001). Effect of estradiol and nonylphenol on mRNA levels of vitellogenin II in the liver of chicken embryos. J. Poultry Sci., 38: 250-257.

S a s a n m i T., Mor i M. (1999). Effects of oestradiol-17 $\beta$ and testosterone on progesterone production in the cultured granulosa cells of Japanese quail. Brit. Poultry Sci., 40: 536-540.

S e chman A., Rzą s a J., P a c z os k a - Eli a s i e w i c z H. (2003). Effect of non-steroidal aromatase inhibitor on blood plasma ovarian steroid and thyroid hormones in laying hen (Gallus domesticus). J. Vet. Med., Ser. A, Physiol., Pathol., Clin. Med., 50: 333-338.

Sechman A., Lak ot a P., Wojtys iak D., Hrabia A., Mika M., Lisowski M., Czeka1ski P., Rząs a J., Kapkowska E., Bednarczyk M. (2006). Sex steroids level in blood plasma and ovarian follicles of the chimeric chicken. J. Vet. Med., Ser. A, Physiol., Pathol., Clin. Med., 53: 501-508.

S e ch man A., P aw łow s k a K., R z ą s a J. (2009). Influence of triiodothyronine ( $\mathrm{T}_{3}$ ) on secretion of steroids and thyroid hormone receptor expression in chicken ovarian follicles. Dom. Anim. Endocrinol., 37: 61-73.

Shodono M., Nakamura T., T a nabe Y., W a kabay a shi K. (1975). Simultaneous determinations of oestradiol-17 $\beta$, progesterone and luteinizing hormone in the plasma during the ovulatory cycle of the hen. Acta Endocrinol., 78: 565-573.

T a kahas hi T., Kaw a s him a M. (2009). Properties of estrogen binding components in the plasma membrane of neurohypophysis in hens and changes in its binding before and after oviposition. Poultry Sci., 88: 2206-2211.

Tilly J.L., K ow a ls k i K.I., J o hns on A.L. (1991). Stage of ovarian follicular development associated with the initiation of steroidogenic competence in avian granulosa cells. Biol. Reprod., 44: $305-314$.

W il s o n S.C., S h a r p P.J. (1975). Effects of progesterone and synthetic luteinizing hormone-releasing hormone on the release of luteinizing hormone during sexual maturation in the hen (Gallus domesticus). J. Endocrinol., 67: 359-369. 
W i 1 s o n S.C., S h a r p P.J. (1976). Induction of luteinizing hormone release by gonadal steroids in the ovariectomized domestic hen. J. Endocrinol., 71: 87-98.

W o ods D.C., J o h n s on A.L. (2005). Regulation of follicle-stimulating hormone-receptor messenger RNA in hen granulosa cells relative to follicle selection. Biol. Reprod., 72: 643-650.

Accepted for printing 18 VII 2011

ANDRZEJ SECHMAN, MIROSŁAWA STARUSZCZAK, JANUSZ RZĄSA

\section{Porównanie stężenia steroidowych hormonów płciowych w osoczu krwi i pęcherzykach jajnikowych kur rasy White Leghorn i zielononóżka kuropatwiana}

\section{STRESZCZENIE}

Celem badań było porównanie tempa nieśności oraz stężenia progesteronu (P4) i estradiolu (E2) w osoczu krwi i pęcherzykach jajnikowych kur rasy White Leghorn (WL) i zielononóżka kuropatwiana (ZK). Do doświadczenia użyto 35-tygodniowych niosących kur WL (linia H22; n = 8) i ZK (linia Z11; $\mathrm{n}=8$ ). Próbki krwi pobierano w momencie zniesienia pierwszego jaja w serii (ok. $0,5 \mathrm{~h}$ przed owulacją), a następnie w 20., 16., 12., 8., 4., 2. i 0 h przed owulacją. Kury (6 szt. z każdej grupy) dekapitowano $2 \mathrm{~h}$ przed owulacją w następnym dniu po ostatnim pobraniu krwi. Z jajnika izolowano stromę, małe (SWF), średnie (MWF) i duże (LWF) białe pęcherzyki niehierarchiczne oraz żółte pęcherzyki hierarchiczne (F6-F1). Stężenie P4 i E2 w osoczu krwi i pęcherzykach jajnikowych oznaczano metodą RIA. Średnie tempo nieśności kur rasy WL było istotnie wyższe niż u kur ZK $(\mathrm{P}<0,05)$. U obydwu ras kur największe stężenie P4 i E2 we krwi zanotowano w 4 . h przed owulacją. U kur WL stężenie P4 w momencie zniesienia jaja oraz w 4. i 2. h przed owulacją było istotnie większe $(\mathrm{P}<0,05)$ niż u kur ZK. Z drugiej jednak strony, u kur ZK w momencie zniesienia jaja, a także w 12., 8. i 4. h przed owulacją zanotowano istotnie większe stężenie E2 w porównaniu z kurami WL $(\mathrm{P}<0,05)$. Stężenie P4 w pęcherzykach LWF i F4-F1 kur rasy WL było mniejsze niż u kur ZK $(\mathrm{P}<0,05)$. W przypadku E2 w pęcherzykach LWF oraz F6-F4 obserwowano odwrotną zależność. Uzyskane wyniki wskazują, że u kur typu nieśnego profil stężenia P4 i E2 we krwi i pęcherzykach jajnikowych zależy od ich genotypu. Istotne różnice w poziomie steroidów płciowych, stwierdzone zarówno we krwi, jak i pęcherzykach jajnikowych badanych ras kur, mogą przyczynić się do wyjaśnienia podłoża endokrynologicznego determinującego ich nieśność i wyniki produkcyjne. 